\title{
Afirmasi Partai Politik Meningkatkan Partisipasi Perempuan: Sebuah Studi di Kabupaten Sumenep
}

Moh Ikmal ${ }^{1}$

ikmal.uny@gmail.com ${ }^{1}$

${ }^{1}$ STKIP PGRI Sumenep Jl. Trunojoyo, Gedungan Barat, Gedungan, Batuan, Kabupaten Sumenep, Jawa Timur 69451, Indonesia

\begin{abstract}
Abstrak
Tujuan penelitian ini adalah untuk mengetahui bagaimana upaya afirmasi partai politik dalam mendorong partisipasi politik perempuan di Kabupaten Sumenep. Penelitian ini menggunakan penelitian kualitatif deskriptif dengan prosedur pengumpulan data berupa wawancara, observasi dan dokumentasi. Teknik validasi data yang digunakan adalah teknik triangulasi sumber berupa person dan paper. Hasil penelitian menunjukkan bahwa upaya yang dilakukan oleh partai politik di Kabupaten Sumenep dalam mendorong partisipasi politik perempuan di antaranya, 1) partai melakukan pendekatan internal/personal; 2) mengembangkan model pendidikan politik kader perempuan secara terprogram, terstruktur dan berkesinambungan; 3) menggelar rapat pada waktu- waktu yang dimungkinkan dapat dihadiri oleh kader perempuan dan waktu yang tidak terlalu disibukkan dengan keperluan rumah tangga.
\end{abstract}

Kata kunci: Afirmasi Politik, Partai Politik, Partisipasi Politik

\begin{abstract}
The purpose of this study is to find out how the affirmative action of political parties in encouraging women's political participation in Sumenep Regency. This study uses descriptive qualitative research with data collection procedures in the form of interviews, observation and documentation. Data validation techniques used are source triangulation techniques in the form of person and paper. The results show that the efforts made by political parties of Sumenep Regency in building women's political participation include, 1) parties taking an internal/personal approach; 2) programmatic, structured and continuous development of the political model of female cadres; 3 ) hold meetings at times that are possible to be attended by female cadres and times that are not too preoccupied with household needs.
\end{abstract}

Keywords: Political Affirmations, Political Parties, Political Participation

\section{Pendahuluan}

Upaya Menghadirkan tata kelola pemerintahan yang demokratis memerlukan lingkungan politik yang inklusif dan proses politik yang responsif bagi semua pihak termasuk kalangan perempuan (Ballington, 2011; Mukarom, 2008; Prajarto, 2005). Diterimanya perspektif perempuan dan partisipasi dalam politik adalah prasyarat pembangunan demokrasi dan konstribusi tata kelola pemerintahan yang baik (good governance). Keterlibatan perempuan dalam ruang publik di samping mampu merespresentasi kepentingan kaum perempuan dalam parlemen, keberadaan mereka juga diharapkan mampu mengubah dinamika gender dalam kamar parlemen (Ballington, 2008). Tingginya angka kematian ibu dan bayi, kasus stunting pada anak, kesehatan reproduksi pada perermpuan, perlindungan kerja bagi Tenaga Kerja Wanita (TKW) adalah sekian persoalan publik yang membutuhkan sentuhan kaum perempuan dalam merumuskan kebijakan publik dengan memperhatikan perspektif kesetaraan dan keadilan gender (Arjani, 2008).

Oleh karenanya, proporsi anggota parlemen perempuan bagaimanapun akan memiliki pengaruh besar terhadap perdebatan politik, baik dalam struktur 
kepengurusan hingga pada penentu kebijakan, baik di parlemen maupun di tubuh partai politik sendiri. Namun dalam realitas politik praktis, disparitas posisi dan peran laki-laki dan perempuan sebagai bagian dari isu gender dalam ruang publik terus menjadi diskusi publik. Laporan UNDP pada tahun 2011 misalnya menyebutkan bahwa pada level global peran perempuan masih dikesampingkan dari struktur kelembagaan yang menentukan prioritas politik dan legislatif. Proporsi kepala negara dan pemerintahan perempuan masih lebih rendah dan turun 5 persen pada tahun 2011 (Inter-Parliamentary Union, 2011, p. 8).

Lebih lanjut, kiprah politik kaum perempuan masih bisa dikatakan stagnan bahkan mengalami kemunduran. Meski 40-50\% anggota partai adalah perempuan, hanya $10 \%$ dari jabatan pimpinan partai yang dijabat oleh perempuan(InterParliamentary Union, 2011, p. 11). Dalam konteks parlemen dunia, 19\% kursi diduduki oleh perempuan naik 16\% pada tahun 2005. Proporsi menteri perempuan lebih rendah, rata-rata 16\% (Inter- Parliamentary Union, 2010).

Tidak jauh berbeda dengan kondisi di Indonesia, potret pelibatan perempuan dalam kuota keterwakilan perempuan dalam parlemen masih jauh dari harapan. Pada pemilu 2004, jumlah keterwakilan perempuan hanya menghasilkan 65 kursi dari total 550 kursi di DPR (setara 11\% kursi). Pada pemilu 2009, hasil pemilu menunjukkan peningkatan keterwakilan perempuan, dengan mendapatkan 101 kursi dari total 560 kursi di parlemen (setara dengan 18\%). Sementara hasil pemilu 2014 justru menunjukkan penurunan, karena angka perolehan kursi perempuan berkurang menjadi 97 kursi dari 560 kursi (setara dengan 17\%) (Ardiansa, 2016).

Pada skala lokal, rendahnya representasi politik perempuan di atas juga terjadi di kawasan Madura, termasuk di Kabupaten Sumenep. Selama hampir dua periode penyelenggaraan pemilu legislatif dari tahun 2009 dan 2014, keterwakilan perempuan dalam lembaga legislatif masih cukup rendah (KPUD Sumenep, 2009). Realitas sosial dan bagaimana posisi perempuan dalam ruang publik di atas banyak dipengaruhi oleh beberapa faktor, salah satunya nilai-nilai budaya yang berkembang pada masyarakat Madura.

Madura merupakan kawasan yang memegang kuat prinsip patriarki. Prinsip ini dapat kita lihat dari pandangan-pandangan orang Madura tentang posisi dan peran laki- laki. Bagi orang Madura, setiap anak laki-laki di Madura sudah dibiasakan untuk berani, kuat, tidak mencla-mencle dan tegas. Anak laki-laki Madura yang penakut dianggap tidak punya kenjantanan. Istilah kettok pala'en (potong alat kelaminmu) dan ngangguy sampèr (memakai rok) sering kali diucapkan kepada lelaki Madura yang penakut. Simbolisasi kultural yang bersifat patriarkis ini di samping mereproduksi alam bawah sadar masyarakat untuk menemukan identitas diri yang sebenarnya, di sisi lain juga mereproduksi sistem relasi dan kuasa gender dalam kehidupan sosial masyarakat, termasuk bagaimana peran dan posisi perempuan dalam ruang publik.

Upaya mendorong partisipasi politik perempuan di Indonesia terus dilakukan oleh pemerintah melalui berbagai peraturan perundang-undangan yang ada. Salah satu bentuk upaya pemerintah dalam mendorong partisipasi politik perempuan dalam ruang publik tersebut adalah dikeluarkannya UU No. 39 Tahun 1999 Tentang HAM, UU No. 2 Tahun 2011 Tentang Partai Politik, UU No. 8 Tahun 2012 Tentang Pemilihan legislatif, UU No. 27 tahun 2009 tentang MPR, DPR, DPD dan DPRD dan beberapa undang- undang yang lain. Harapan terhadap perubahan kualitas demokrasi melalui kebijakan yang bersifat regulative yang lebih memihak kepada 
kelompok perempuan diatas semakin baik dan proporsional seiring dengan jumlah kontestan partai politik yang semakin sedikit, dari Pemilu 2009 yang berjumlah 38 Partai menjadi hanya 12 partai politik pada tahun 2014 dengan asumsi peluang terakumulasinya suara perempuan menjadi kursi juga semakin besar. Tetapi yang terjadi adalah hasil Pemilu 2014 tidak menunjukkan hasil yang menggembirakan bagi keterpilihan perempuan. Kedua hal yang disebutkan di awal belum mampu mendorong angka keterpilihan perempuan menjadi lebih baik dan cenderung stagnan.

Sementara disisi lain, dorongan komunitas internasional untuk menghapus diskriminasi dan memberdayakan perempuan terus dilakukan (Khotimah, 2009; Wibowo, 2011). Tahun 2000, PBB mengakui peran penting perempuan dalam pembangunan dengan memasukkan pemberdayaan perempuan sebagai salah satu Millennium Development Goals (MDGs), namun tak satupun kawasan di dunia yang dapat mencapai 30 persen perempuan dalam posisi pembuatan keputusan (Arjani, 2008). Meski terdapat perkecualian dan praktek terbaik dalam bidang ini, beberapa hambatan masih menghantui partisipasi perempuan secara penuh dan setara sebagai pihak yang bertanding. Stereotipe peran dan bias gender masih meluas, dalam berbagai tingkatan, di semua negara di dunia dan tercermin dalam tatanan sosial, ekonomi, dan politik (Warits, 2012).

Berdasarkan realitas diatas tentu upaya untuk mendorong partisipasi politik perempuan membutuhkan upaya regulasi terencana dan terus menerus baik bagi pemerintah sebagai regulator maupun elemen partai politik sendiri dalam mendorong dan memperkuat posisi perempuan dalam ruang publik yang tidak hanya pada aspek administrative ketersediaan kuota 30\% keterwakilan perempuan dalam komposisi partai politik sebagai persyaratan administrative pendirian partai politik maupun dalam penyertaan daftar bakal calon perempuan yang diusung dalam pemilu sebagaimana diatur dalam undang-undang diatas. Upaya diatas juga harus melompat lebih jauh adalah bagaimana memperkuat kapasitas organisasi internal partai yang lebih kuat melalui kerangka hukum dan dokumen peraturan yang cukup peka gender dengan cara melibatkan partisipasi perempuan dalam dewan pengurus dan struktur pembuatan keputusan sampai pada upaya mendorong partisipasi politik perempuan baik pada priode pra pemilihan, priode pemilihan sampai pada pasca pemilihan. Upaya diatas tentu menjadi faktor utama dalam melakukan langkah reformasi kelembagaan partai politik yang lebih peka gender. Melalui kerangka pemikiran diatas maka peneliti merasa tertarik untuk menjelaskan secara deskriptif potret representasi politik perempuan dan upaya partai politik dalam mendorong partisipasi politik perempuan di kabupaten Sumenep.

\section{Tinjauan Pustaka}

\section{Representasi Politik}

Perkembangan teori representasi politik, sangat dipengaruhi oleh perubahan fenomena politik. Di antara berbagai definisi representasi politik yang tampaknya sederhana dan umum dipahami adalah konsep representasi yang terkait dengan pemilihan umum. Konsep demikian, misalnya, dituliskan oleh Enrique Perruzotti, seorang professor di Torcuato di Tella University, di dalam tulisanya Representation, Accountability, and Civil Society. Dia mengatakan Representatif (wakil) is someone who has been authorized to act with relative independence of the electorat', yaitu 
seseorang yang memperoleh otoritas untuk bertindak dengan kebebasan yang relatif dari para pemilihnya (Suseno, 2013, p. 16).

Berdasarkan konsep ini terlihat bahwa seorang wakil tidak semata-mata bertindak atas kehendak rakyat yang diwakilinya, namun wakil ini memiliki kebebasan meskipun relatif untuk mempertimbangkan dan mengambil tindakan terbaik. Wakil tidak hanya mengikuti saja apa-apa yang menjadi tuntutan dan kehendak dari rakyat. Untuk itulah diperlukan adanya kepercayaan dari masyarakat, agar ketika dalam menentukan kebijakan, pengambilan keputusan dan dalam bertindak, masyarakat mempercayai bahwa itu adalah upaya terbaik dari wakil untuk mereka.

Menurut Micheal Saward "Generally a representative is regarded as one who stands for or acts for an (absent) other. They may do so by being a delegateacting on the express wishes of the representative-or a trustee, acting in the perceived best interests of the represented." Secara umum seorang wakil dianggap sebagai seseorang yang berdiri mengatasnamakan atau bertindak atas nama orang lain (yang tidak hadir). Mereka melakukanya sebagai delegasi yang bertindak berdasarkan keinginan yang diekspresikan oleh (pihak) yang diwakili atau sebagai trustee (kepercayaan), yang bertindak berdasarkan apa yang dipandang sebagai kepentingan dari yang diwakilinya (Suseno, 2013, p. 18).

\section{Partai Politik}

Kehadiran partai politik tidak bisa kita lepaskan dari sisi historis. Jika dilacak secara historis paling tidak kemunculan partai politik bisa dilihat dari tiga teori. Pertama, teori struktural kelembagaan di mana asal usul partai politik itu hadir karena adanya keterhubungan secara kelembagaan antara parlemen dan partai politik itu sendiri. Kedua, teori situasi historis di mana partai politik hadir dan menjelma menjadi sebuah organisasi massa dikarenakan kehadirannya adalah merupakan upaya untuk menjawab berbagai krisis sosial dan perubahan masyarakat. Ketiga, teori pembangunan yang menjelaskan bahwa kemunculan sebuah partai politik itu tidak lain adalah meruapakan respon modernitas dan kondisi sosial ekonomi masyarakat (Surbakti, 1992, p. 113).

Beragam definisi partai politik telah dikemukakan oleh beberapa ahli, di antaranya menurut Carl J. Friedrich menyebutkan bahwa "Partai politik adalah sekelompok manusia yang terorganisir secara stabil dengan tujuan merebut atau mempertahankan penguasaan terhadap pemerintahan bagi pimpinan partainya dan berdasarkan penguasaan ini, memberikan kepada anggota partainya kemanfaatan yang bersifat idiil serta materiil" (Surbakti, 1992, p. 403). Sedangkan menurut Sigmund Neuman, partai politik merupakan organisasi artikulatif di mana pelaku politik yang terlibat di dalamnya memusatkan perhatiannya pada bagaimana menguasai kekuasaan pemerintahan dan strategi untuk memperoleh dukungan rakyat (Neumann, 1956, p. 60).

Keberadaan sebuah organisasi politik tentu memiliki fungsi dan tujuan sebagai arah capaian yang harus dilakukan. Miriam Budiardjo menjelaskan beberapa fungsi partai politik di antaranya (A. Rahman H.I, 2007, pp. 103-104); 1.) Komunikasi Politik. Fungsi komunikasi politik ini berarti bahwa partai politik berfungsi mengkomunikasikan berbagai tuntutan dan dukungan masyarakat (ruled) kepada pemerintah (ruler). Fungsi ini juga menunjukkan bahwa parpol turut menyebarluaskan rencana-rencana dan kebijakan pemerintah. 2.) Sosialisasi Politik. 
Keberadaan partai politik di samping berfungsi mengkomunikasikan berbagai keinginan-keinginan dan tuntutan masyarakat kepada pemerintah, parpol juga berperan dan bertanggung jawab untuk membentuk dan mengenalkan sistem budaya politik yang berlaku, mendidik warga negara untuk memiliki kesadaran dan tanggung jawab sebagai warga negara yang baik dengan menempatkan kepentingan negara di atas kepentingan pribadi dan kelompok. 3.) Rekrutmen Politik. Rekrutmen politik merupakan fungsi di mana partai politik melalukan proses regenerasi kepemimpinan internal dengan mengajak orang yang memiliki kompetensi untuk berpartisipasi dalam proses politik. Proses regenerasi kepemimpinan internal dilakukan dalam rangka menjamin keberlangsungan dan kelestarian partai, sekaligus merupakan salah satu cara melakukan seleksi kepemimpinan secara profesional. 4.) Pengatur Konflik Politik. Fragmentasi sosial dan partai politik bukan tidak mungkin akan menimbulkan konflik sosial dan konflik kepentingan di dalamnya. Oleh karena itu, keberadaan partai politik sebagai pengatur konflik politik adalah turut membantu mengatasi konflik di antara masyarakat atau sekurang-kurangnya dapat diatur sedemikian rupa sehingga akibat negatifnya dapat ditekan seminimal mungkin.

Beberapa fungsi partai politik diatas sejalan dengan amanah UndangUndang Nomor 2 Tahun 2011 tentang Partai Politik Pasal 11 ayat 1 yang menyatakan bahwa partai politik adalah sebagai sarana; a) Pendidikan politik bagi anggotanya dan masyarakat luas, b) Penciptaan iklim yang kondusif serta sebagai perekat persatuan dan kesatuan bangsa untuk mensejahterakan masyarakat, c) Penyerap, penghimpun, dan penyalur aspirasi politik masyarakat secara konstitusional dalam merumuskan dan menetapkan kebijakan negara, d) Partisipasi politik warga negara Indonesia; dan e) Rekrutmen politik.

\section{Partisipasi Politik}

Partisipasi menjadi salah satu prinsip mendasar dari good government. Partisipasi berasal dari bahasa latin yaitu pars yang artinya bagian dan capere yang artinya mengambil peranan dalam aktivitas atau kegiatan politik negara. Apabila digabungkan berarti "mengambil bagian". Dalam bahasa Inggris, partisipate atau participation berarti mengambil bagian atau peranan. Jadi partisipasi politik berarti mengambil peranan dalam aktivitas atau kegiatan politik negara (Suharno, 2004, pp. 102-103).

Partisipasi politik adalah salah satu aspek penting suatu demokrasi. Partisipasi politik merupakan ciri khas dari modernisasi politik. Adanya keputusan politik yang dibuat dan dilaksanakan oleh pemerintah menyangkut dan mempengaruhi kehidupan warga negara, maka warga negara berhak ikut serta menentukan isi keputusan politik. Oleh karena itu, yang dimaksud dengan partisipasi politik menurut Hutington dan Nelson, yang dikutip oleh Cholisin (Cholisin, 2007, pp. 150-151), adalah kegiatan warga negara yang bertindak sebagai pribadi-pribadi yang dimaksud untuk mempengaruhi pembuatan keputusan oleh pemerintah. Partisipasi bisa bersifat individual atau kolektif, terorganisir atau spontan, mantap atau secara damai atau kekerasan, legal atau illegal, efektif atau tidak efektif (Budiardjo, 2008, p. 369).

Selanjutnya Ramlan Surbakti, sebagaimana yang dikutip oleh Cholisin, memberikan definisi singkat mengenai partisipasi politik sebagai bentuk keikutsertaan warga negara biasa dalam menentukan segala keputusan yang menyangkut atau 
mempengaruhi hidupnya (Cholisin, 2007, pp. 150-151). Oleh sebab itu, di negaranegara demokrasi pada umumnya menganggap bahwa partisipasi masyarakatnya lebih banyak, maka dianggap akan lebih baik. Dalam implementasinya tingginya tingkat partisipasi menunjukkan bahwa warga negara mengikuti dan memahami masalah politik dan ingin melibatkan diri dalam kegiatan-kegiatan itu. Sebaliknya, tingkat partisipasi yang rendah pada umumnya dianggap sebagai tanda yang kurang baik, karena dapat ditafsirkan bahwa banyak warga tidak menaruh perhatian terhadap masalah kenegaraan.

Berbagai pendapat yang dikemukakan oleh para ahli di atas dapat ditarik kesimpulan bahwa partisipasi politik adalah hal-hal yang berkaitan dengan kegiatan seseorang atau sekelompok orang dalam hal penentuan atau pengambilan kebijakan pemerintah baik itu dalam hal pemilihan pemimpin ataupun penentuan sikap terhadap kebijakan publik yang dibuat oleh pemerintah untuk dijalankan, yang dilakukan secara langsung atau tidak langsung dengan cara konvensional ataupun dengan cara non konvensional atau bahkan dengan kekerasan (violence).

Lebih lanjut, partisipasi politik merupakan suatu aktivitas tentu dipengaruhi oleh beberapa faktor. Menurut Ramlan Surbakti, ada dua variabel penting yang mempengaruhi tinggi rendahnya tingkat partisipasi politik seseorang (Surbakti, 1992, p. 140). Pertama, aspek kesadaran politik terhadap pemerintah (sistem politik). Maksud kesadaran politik adalah kesadaran hak dan kewajiban warga negara. Misalnya hak politik, hak ekonomi, hak perlindungan hukum, kewajiban ekonomi, kewajiban sosial, dan lainnya. Kedua, menyangkut bagaimana penilaian serta apresiasi terhadap kebijakan pemerintah dan pelaksanaan pemerintahnya.

Selain itu, ada faktor yang berdiri sendiri (bukan variabel independen). Artinya bahwa rendah kedua faktor itu dipengaruhi oleh faktor-faktor lain, seperti status sosial, status ekonomi, afiliasi politik orang tua, dan pengalaman beroganisasi. Status sosial mencakup kedudukan seseorang berdasarkan keturunan, pendidikan, pekerjaan, dan lain- lain. Selanjutnya status ekonomi, yaitu kedudukan seseorang dalam lapisan masyarakat, berdasarkan pemilikan kekayaan. Seseorang yang mempunyai status sosial dan ekonomi tinggi diperkirakan tidak hanya mempunyai pengetahuan politik, akan tetapi memiliki minat serta perhatian pada politik dan kepercayaan terhadap pemerintah (Surbakti, 1992, pp. 144-145).

Dalam konteks penelitian ini, konsep representasi politik, partai politik, dan partsipasi politik digunakan untuk melihat bagaimana afirmasi partai politik dalam memberikan ruang partisipasi bagi perempuan. Tujuannya untuk merepresentasikan kepentingan perempuan di ruanh public, dengan studi kasus di Kabupaten Sumenep.

\section{Metode}

Penelitian ini merupakan jenis penelitian kualitatif-deskriptif (Moleong, 2002, p.3). Pendekatan yang digunakan dalam penelitian ini adalah pendekatan naturalistik, untuk mengungkap ontologi paradigma penelitian. Dengan pendekatan ini, peneliti bersifat aktif dalam melakukan interaksi dengan subjek penelitian dalam situasi apa adanya tanpa adanya rekayasa, sehingga data diperoleh dari fenomenanya yang bersifat asli dan natural (Sulistyo, 2006, p. 5).

Sumber data yang digunakan dalam penelitian ini adalah jenis person dan paper (Arikunto, 2002, p. 107). Subjek penelitian berupa person adalah kelompok elit muda dan aparat desa setempat. Sementara subjek penelitian berupa paper adalah 
dokumen-dokumen tertulis baik berupa perundang-undangan ataupun bahan pustaka lainnya yang memiliki relevansi dengan data penelitian.

Penentuan subjek penelitian berupa person dilakukan dengan teknik purposif. Dengan teknik ini, ditetapkan kriteria-kriteria sesuai dengan tujuan penelitian, yaitu penduduk tetap di desa tempat penelitian dilaksanakan. Sedangkan subjek berupa paper digunakan sebagai sumber data-data sekunder sesuai dengan tujuan penelitian. Sementara untuk teknik pengumpulan data dalam penelitian ini berupa kata-kata dan tindakan yang diperoleh secara langsung (data primer), selebihnya adalah data tambahan berupa literatur, dokumen dan lain-lain.

Beberapa teknik pengumpulan data yang digunakan dalam penelitian ini adalah, pertama, observasi melalui pengamatan secara sistematis terhadap obyek yang diteliti (Patton, 1990, p. 56). 2). Kedua, wawancara mendalam (indepth interview), teknik wawancara merupakan bentuk percakapan langsung dan tatap muka (face to face) dengan maksud tertentu (Arikunto, 2002, p.135). Ketiga, dokumentasi, melalui pengkajian atas berbagai dokumen resmi baik yang bersifat internal maupun eksternal, seperti arsip berita.

Sementara untuk mengukur validitas penelitian, peneliti menggunakan teknik triangulasi, yaitu teknik pemeriksaan data yang memanfaatkan sesuatu yang lain di luar data itu untuk keperluan pengecekan atau sebagai pembanding terhadap data itu (Arikunto, 2002, p. 135). Peneliti menggunakan jenis triangulasi yang membandingkan dan mengecek ulang data hasil wawancara dengan isi dokumen.

\section{Hasil dan Pembahasan}

\section{Tantangan Politik Afirmasi Partai dalam Mendorong Partisipasi Politik Perempuan di Kabupaten Sumenep}

Realitas kesenjangan antara laki-laki dan perempuan di kehidupan publik dan politik merupakan sebuah tantangan global yang dihadapi oleh masyarakat dunia pada abad ke 21. Meskipun telah ada berbagai konvensi, kovenan, dan komitmen internasional, namun secara rata-rata jumlah perempuan di dalam parlemen di dunia ini hanya 18,4 persen. Dari 190 negara, hanya tujuh negara di mana perempuan menjadi presiden atau perdana menteri. Hadirnya perempuan sebagai bagian dari kabinet yang ada di dunia ini atau walikota, jumlahnya tak mencapai 7 dan 8 persen (Paxton \& Hughes, 2007).

Indonesia berada di nomor 80 dari 156 negara yang ada di dalam Indeks Pembangunan Gender atau Gender Development Index (GDI) pada tahun 2007. Pada tahun 2009, angka ini merosot ke urutan 90, artinya perempuan di Indonesia masih belum menikmati hak dan standar yang sama dengan para laki-laki. Untuk itu, guna menghadirkan keterwakilan perempuan di ruang publik, konsitusi memberikan ruang yang terbuka bagi kalangan perempuan untuk duduk dalam jabatan-jabatan politik dan pemerintahan. Melalui ketentuan kuota 30\% keterwakilan perempuan dalam tubuh partai politik diharapkan dapat mendorong tingginya partisipasi politik dalam kontestasi politik pemilu.

Lebih lanjut, Indonesia berkomitmen untuk menjalankan prinsip kesetaraan gender melalui berbagai komitmen nasional dan internasional. Undang-undang Dasar 1945 menjamin kesetaraan antara laki-laki dan perempuan, serta pengarusutamaan gender telah diadopsi menjadi sebuah kebijakan untuk mengintegrasikan perspektif gender ke dalam kebijakan, perencanaan dan penganggaran. Tindakan afirmatif 
(affirmative action) juga sudah diperkenalkan pada UU No. 10/2008 tentang Pemilihan Umum untuk memastikan setidaknya 30 persen perempuan dicalonkan dalam daftar calon anggota legislatif untuk memberikan ruang keterwakilan perempuan dalam politik.

Adapun partai politik sebagai bagian dari upaya legal dalam memperjuangkan aspirasi politik, memiliki kewajiban yuridis dan moral untuk melaksanakan pendidikan politik bagi warga. Memberdayakan kader perempuan di tengah minimnya partisipasi politik perempuan adalah merupakan fungsi penting bagi partai politik dalam melakukan pendidikan politik bagi masyarakat. Partai politik melaksanakan fungsi pendidikan politik, yang bertujuan untuk membentuk kepribadian politik, kesadaran politik dan partisipasi politik (Ruslan, 2000). Muara dari pendidikan politik adalah tingginya partisipasi politik kader dalam proses politik praktis. Pendidikan politik oleh partai memainkan peranan strategis dalam membentuk warga negara terutama kader partai guna memiliki kepribadian politik, kesadaran politik dan mampu berpartisipasi secara aktif dan responsif sebab kader merupakan bagian dari aktor politik praktis yang terlibat dalam sirkulasi kekuasaan publik.

Utamanya terhadap kader perempuan, pendidikan politik oleh partai dapat menjadi batu loncatan untuk meningkatkan partisipasi politik kader perempuan baik di tataran internal partai maupun di pemerintahan. Dalam konteks ini, partisipasi politik kader perempuan partai di Indonesia masih relatif rendah. Salah satunya dapat dilihat dari kuantitas perempuan yang terwakili di lembaga legislatif. Hasil penelitian Pusat Kajian Politik Universitas Indonesia tahun 2014 mengungkapkan bahwa keterwakilan perempuan dalam parlemen di Indonesia tidak pernah melebihi angka $20 \%$. Jauh dari harapan kuota 30\% keterwakilan perempuan sebagai salah satu langkah afirmasi politik untuk meningkatkan partisipasi perempuan dan cara khusus untuk mencapai kesetaraan gender dalam berpolitik.

Afirmasi politik merupakan kebijakan yang dikeluarkan oleh pemerintah pertama kali melalui Undang-Undang No.10 tahun 2008 tentang pemilu anggota DPR, DPD dan DPRD. Sistem kuota adalah bentuk tindakan afirmasi yang harus dipenuhi partai dalam mengajukan calon anggota legislatif dan kepengurusan partai. Namun, kuota keterwakilan perempuan tidak akan efektif jika pengetahuan, pemahaman dan keterampilan politik perempuan masih minim. tetapi mampu mengambil peran dan mempengaruhi pengambilan kebijakan politik.

Tindakan afirmasi yang terdapat dalam undang-undang pemilu belum dapat menjamin calon anggota legislatif perempuan untuk terpilih (Susiana \& Cahyaningrum, 2010, p. 27). Aturan tersebut masih perlu dilengkapi dengan aturanaturan lain yang dapat menjamin agar calon anggota legislatif perempuan terpilih sehingga dapat meningkatkan keterwakilan perempuan di lembaga legislatif. Salah satu langkah strategis untuk mendukung kesuksesan pencapaian tujuan afirmasi ialah penekanan pada peranan partai politik dalam melaksanakan pendidikan politik kepada kader perempuan secara serius, terprogram, dan berkelanjutan.

Menilik posisi, peran, serta relasi perempuan dan politik, maka pembahasan akan tertuju pada konsep gender dan politik sebab persepsi gender mempengaruhi partisipasi perempuan dalam berpolitik. Politik dan perilaku politik selama ini dipandang sebagai aktivitas maskulin. Perilaku politik yang lekat dengan sikap kemandirian, ketegasan, agresif, dan keras, dinilai tidak cocok dengan karakter 
perempuan yang digambarkan sebagai pribadi yang lemah lembut, pasrah dan penurut. Oleh karena itu, untuk meluruskan persepsi tersebut, partai politik sebagai infrastruktur politik di masyarakat, memainkan peran strategis dalam memberikan pendidikan politik kepada kader perempuan dan masyarakat. Namun, dalam realitas politik di lapangan, ditemukan beberapa kendala yang dihadapi partai politik dalam pelaksanaan pendidikan politik.

Dalam konteks Kabupaten Semenep, kendala tersebut antara lain, pertama, kendala utama yang dihadapi partai politik di Kabupaten Sumenep dengan perolehan jumlah kursi terbanyak pada pemilu legislatif 2014 (PPP, PKB, PAN, Demokrat) berasal dari sisi internal perempuan, yakni rendahnya kepercayaan diri perempuan untuk bergabung dan terlibat aktif dalam politik praktis. Meski mereka merupakan kader sekaligus menjadi bagian dari kepengurusan partai, sebagaimana Sistem kuota gender harus terpenuhi pada masing-masing kepengurusan partai maupun dalam usulan daftar bakal calon anggota legislatif, namun dalam politik praktis keberadaan dan peran mereka tidak begitu nampak. Hal ini dapat kita lihat dari sejauh mana kemampuan elektabilitas caleg perempuan yang bertarung dalam kontestasi pemilu legislatif 2014. Dari 12 partai politik peserta pemilu legislatif 2014, hanya partai Gerindra dan PAN yang berhasil memperoleh kursi perempuan dalam jabatan kursi legislatif (KPUD Sumenep, 2014).

Kondisi demikian diperparah juga dengan kecendrungan kaum perempuan yang kurang tertarik untuk diberikan pelatihan dan pembinaan dalam peningkatan kapasitas di bidang politik praktis, Mereka cenderung suka kegiatan-kegiatan santai, seperti arisan dan atau sekedar berfoto ria dan ini hampir menjadi fenomena umum pada setiap partai politik yang ada (PPP, PLN, dan Demokrat, 6 Mei 2019).

Sementara itu di beberapa partai politik lainnya seperti Partai Keadilan Sejahtera (PKS) terlihat nampak berbeda kegiatan kader perempuan PKS. Mereka memiliki prinsip dan pandangan bahwa politik bukan hanya seputar pemerintahan, namun lebih daripada itu mereka melakukan kerja-kerja internal partai, pemberdayaan ekonomi dan keluarga serta kajian-kajian Islam. Begitu juga di Partai Golkar. Kebanyakan perempuan di Partai Golkar tidak begitu tertarik terhadap kegiatankegiatan yang bersifat politis dan tidak begitu antusias untuk terlibat ke dalam politik praktis seperti masuk ke dalam pemerintahan dan parlemen (PPP, PLN, dan Demokrat, 13 Mei 2019). Hal ini didasari pada anggapan bahwa kondisi yang terdapat di lapangan selama ini menunjukkan bahwa, penentu seseorang bisa menang dalam kontestasi pemilu adalah pada seberapa banyak uang yang dimiliki, bukan tergantung pada kualitas dan figur, sehingga meningkatkan kualitas dan kapasitas di bidang politik tidak menjadi begitu penting. Perempuan kurang memiliki motivasi yang kuat untuk ikut dalam proses politik dan enggan untuk menegaskan posisi politiknya serta menghindar dari lingkungan kompetitif (PPP, PLN, dan Demokrat, 20 Mei 2019).

Kedua, dukungan dan izin dari keluarga. Perempuan yang bekerja dan bergerak dalam segala macam aktivitas sosial politik harus mendapatkan izin keluarga. Kader perempuan yang berpotensi untuk memimpin dan aktif dalam kegiatan partai terkadang terkendala oleh izin keluarga. Jadi, semuanya tidak bisa dinyatakan bahwa ketidakaktifan perempuan di partai adalah faktor kurangnya pengetahuan politik kader atau tidak melek politik. Izin keluarga juga terkait dengan masalah waktu (Ningsih, 27 Mei 2019). 
Kader perempuan cenderung sulit membagi waktu antara urusan keluarga dan kegiatan politik praktis di partai sehingga mempengaruhi partisipasinya dalam kegiatan dan program partai. Dalam partai politik, tidak ada jam kerja yang pasti. Perempuan yang aktif dalam politik praktis akan memiliki peran ganda, secara biologis menjadi istri dan ibu dalam ranah domestik serta secara moril dalam tanggung jawabnya sebagai pengelola partai.

Ketika perempuan dihadapkan pada dua pilihan antara aktivitas politik di luar rumah atau fokus mengurus keluarga, pilihannya cenderung akan jatuh pada pilihan kedua. Namun, hal yang cukup menarik terjadi, jika masalah waktu disandingkan dengan faktor ekonomi. Tampaknya akan ditemukan fakta lain bahwa kader perempuan dengan kemampuan ekonomi yang mencukupi akan lebih aktif daripada perempuan yang memiliki keterbatasan dalam keadaan keuangan. Hal ini dapat dimaklumi sebab perempuan dengan keadaan ekonomi yang cukup dapat menggunakan jasa pengasuh anak untuk merawat dan mengasuh anaknya ketika ia berkegiatan di luar rumah. Berbeda halnya dengan perempuan dari keluarga sederhana bahkan kurang mampu. Mereka akan mengurus anaknya sendiri karena tidak mampu menyewa jasa pengasuh anak, bahkan perempuan ini harus bekerja di luar rumah untuk mencukupi kebutuhan ekonomi keluarga sehingga berkegiatan di partai diletakkan dalam urusan belakangan.

Selain itu, melakukan kegiatan di partai juga membutuhkan biaya sebab partai tidak selalu menyediakan dana akomodasi untuk kader. Partisipasi politik berupa keaktifan dalam kegiatan partai dipengaruhi oleh kendala pendanaan dalam mengikuti pendidikan politik di partai bagi kader perempuan. Meskipun begitu, terlepas dari mampu atau tidaknya seorang perempuan secara ekonomi, persoalan dana untuk kegiatan politik dapat menjadi satu kendala tersendiri. Jika partai telah membebaskan dana untuk kader yang maju dalam pemilihan umum guna bertarung untuk mendapatkan jabatan politik tertentu, ia harus mampu membiayai dirinya sendiri. Inilah salah satu kriteria yang dilihat oleh partai. Jika perempuan tidak bisa mencukupi secara ekonomi, bagaimana ia akan membiayai kegiatan politik pencalonan.

Ketiga, budaya politik patriarki yang masih kental di masyarakat Madura tidak terkecuali di Kabupaten Sumenep menjadikan posisi dan peran perempuan dianggap sebelah mata. Budaya patriarki merupakan pola dalam suatu sistem hubungan sosial yang di dalamnya didominasi oleh kaum laki-laki. Terdapat ketimpangan peran yang disebabkan oleh persepsi bahwa laki-laki lebih berkuasa atas perempuan karena menonjolkan kelemahan-kelemahan yang dimiliki perempuan (Mardhatillah, 2014; Warits, 2012; Yuriadi, 2016).

Dalam bidang sosial, bahkan di negara maju seperti Amerika Serikat, hal tersebut masih kental di mana posisi kepemimpinan perempuan dalam organisasi kelas pekerja terbilang sedikit padahal perempuan memainkan peran yang penting dalam perjuangan kelas pekerja. Budaya patriarki semakin terasa jika merambah pada dunia politik. Stereotip peran seksual menyatakan bahwa dunia politik adalah milik laki-laki. Persepsi politik jika dikaitkan dengan karakteristik perempuan maka akan ditemukan sebuah kontradiksi. Politik dipersepsikan sebagai dunia yang keras, kejam dan kotor sedangkan perempuan merupakan makhluk yang lemah. Di sinilah posisi dan peranan perempuan menjadi minor ketika dihadapkan dengan peranan gender. 
Lebih lanjut, pengetahuan politik dan political efficacy laki-laki dianggap lebih tinggi daripada perempuan karena dibesarkan dengan budaya yang mendukung hal tersebut. Political efficacy adalah istilah yang mengacu pada perasaan bahwa partisipasi politik seseorang memiliki dampak terhadap proses politik. Bila membicarakan peran politik perempuan, tidak bisa diartikan secara sempit seperti melihat politik dalam kaca mata formal di bidang legislatif, eksekutif, dan yudikatif. Oleh karena eksistensi politik terwujud dalam aspek kehidupan bersama pada tingkat lokal maupun kepekaan terhadap permasalahan yang ada. Ikut atau tidaknya perempuan dalam bentuk partisipasi politik bergantung pada political efficacy.

Umumnya perempuan yang aktif dalam politik kepartaian, dilandasi oleh beberapa alasan, di antaranya adalah bahwa hak politik merupakan bagian dari hak asasi manusia dan hak politik perempuan merupakan hak yang harus dilindungi, dihormati dan dipenuhi oleh negara dan diterima oleh masyarakat. Indonesia telah meratifikasi beberapa kesepakatan internasional tentang pengakuan dan perlindungan hak-hak perempuan termasuk hak-hak politik. Jadi, perempuan yang aktif berpolitik praktis dalam partai, sesungguhnya hanya menjalankan hak politik yang dimilikinya. Kedua, bahwa politik merupakan urusan setiap individu terlepas dari jenis kelamin dan peranan gender yang melekat dalam konstruksi sosial budaya masyarakat. Politik juga urusan perempuan. Berpolitik adalah sebuah keniscayaan dan setiap orang tidak dapat melepaskan diri dari politik sebab politik hadir di ruang publik manapun. Selanjutnya dikatakan bahwa politik berkaitan dengan penunaian kewajiban, ideologi, dan wawasan pengetahuan masyarakat (Darmawan, 2017).

Sedangkan pertimbangan ketiga melihat bahwa perempuan sama seperti laki-laki memiliki kebutuhan dan kepentingan politik yang harus diperjuangkan. Kedua hal ini cenderung lebih berhasil apabila diperjuangkan oleh perempuan sendiri, sebab mereka lebih mengerti kebutuhan dan kepentingannya dibanding pihak lain. Jalur politik melalui partai politik merupakan jalur yang tepat untuk itu sebab politik lekat dengan kekuasaan dan tujuan utama partai politik adalah merebut dan mempertahankan kekuasaan untuk menerapkan kebijakan dan program-programnya.

Keempat, kendala yang berasal dari internal partai politik. Persoalan dana pendidikan politik nyatanya masih menjadi kendala yang dirasakan oleh partai politik untuk melaksanakan pendidikan politik kader, sehingga cukup menghambat gerak partai dalam merencanakan dan melaksanakan program untuk memberdayakan kader. Umumnya negara-negara di dunia, mengandalkan pendanaan partai pada sumbangan anggota. Besarnya biaya yang ditetapkan tergantung kebijakan internal partai politik masing-masing. Pemerintah juga memberikan bantuan keuangan bagi partai politik. Bantuan tersebut utamanya ditujukan untuk pelaksanaan pendidikan politik bagi kader khususnya dan bagi masyarakat pada umumnya. Untuk alokasi dana bantuan dari pemerintah yang harus diberikan 60\% untuk kegiatan pendidikan politik.

\section{Afirmasi Politik Partai dan Penguatan Partisipasi Politik Perempuan di Kabupaten Sumenep}

Sistem kuota perempuan sebagai bagian dari langkah affirmative action dalam mendorong partisipasi politik perempuan merupakan satu kebutuhan terbesar dalam menjamin perluasan partisipasi politik masyarakat sekaligus menjamin kepentingan perempuan dapat tercapai. Namun demikian, meski sudah diatur secara 
konstitusional, tantangan kultural serta dogma-dogma agama menjadi problem serius. Oleh karena itu, berbagai upaya yang dilakukan partai politik dalam membangun political equality dan social justice yang dalam meningkatkan partisipasi politik perempuan partai di Kabupaten Sumenep diantaranya (PPP, PKB, Gerindra, PAN, dan Demokrat, 3 Juni 2019).

Pertama, partai melakukan pendekatan internal/personal. Partai mengedepankan cara-cara persuasif untuk menarik hati dan simpati kader perempuan guna aktif dan partisipatif dalam politik praktis. Pendekatan internal dilakukan untuk mengetuk kesadaran kader perempuan untuk menyadari peranannya sebagai warga negara yang memiliki hak, kewajiban dan tanggung jawab politik yang sama seperti kaum laki-laki.

Partisipasi politik kader perempuan dalam partai politik tidak harus didefinisikan secara kaku dalam satu pandangan bahwa partisipasi politik berarti ambisi yang berlebihan dari kader perempuan untuk mencalonkan diri menjadi anggota legislatif, pemilihan kepala daerah dan wakil kepala daerah maupun pemilihan presiden dan wakil presiden. Bentuk partisipasi politik kader perempuan dalam partai politik memiliki konteks yang lebih luas yakni ikut menginisiasi dalam program/kegiatan partai; terlibat aktif dalam program/kegiatan partai; ikut dalam perdebatan menentukan kebijakan/sikap partai; aktif dalam kepengurusan partai; ikut serta menyukseskan program partai dalam lingkungan social masyarakatnya; memberikan pencerahan dan sosialisasi politik kepada masyarakat sebagai perpanjangan tangan partai dalam rangka melaksanakan fungsi-fungsi partai politik.

Kedua, pengembangan model pendidikan politik kader perempuan secara, terprogram, terstruktur dan berkesinambungan. Undang-undang partai politik tidak memberikan patokan yang jelas mengenai mekanisme pengkaderan partai sehingga tergantung kepada political will dan political action masing-masing partai politik. Pengkaderan memegang peranan penting dalam pemberian pengetahuan, pemahaman dan keterampilan politik. Kaderisasi merupakan proses penyiapan sumber daya manusia agar kelak menjadi pemimpin yang mampu membangun peran dan fungsi organisasi secara lebih baik.

Sedangkan rekrutmen politik merupakan jalan untuk menyaring, menyeleksi serta menempatkan kader pada jabatan politik baik di internal partai maupun pemerintahan. Untuk menjadi kader yang berkualitas dan terseleksi dalam mengisi jabatan-jabatan publik, perempuan kader partai harus mendapatkan pendidikan politik yang jelas, komprehensif dengan strategi, materi dan metode yang sesuai dengan kebutuhan perempuan itu sendiri.

Ketiga, upaya untuk mengatasi kendala waktu, solusinya dengan menggelar rapat pada waktu-waktu yang dimungkinkan dapat dihadiri oleh kader perempuan dan waktu yang tidak terlalu disibukkan dengan keperluan rumah tangga. Selain itu, juga dilakukan upaya dalam hal mengonfirmasi kader perempuan jika akan ditugaskan untuk kegiatan partai yang dirasa akan memakan waktu yang lama dan berkemungkinan akan meninggalkan keluarganya

Keempat, kebijakan politik tanpa mahar. Meski kebijakan ini hanya untuk kalangan partai politik tertentu (Nasdem), namun mereka memiliki pandangan jika pendidikan politik ini akan mampu mendorong partisipasi kalangan perempuan untuk aktif dalam politik praktis tanpa kendala biaya. Ini merupakan bagian dari 
pendidikan politik untuk memberikan pencerdasan politik dan mengubah persepsi masyarakat bahwa politik merupakan suatu aktivitas yang mahal.

Gagasan tanpa mahar politik merupakan tagline Partai Nasdem yang membedakannya dengan partai lain. Tujuannya untuk meminimalisir kendala pendanaan politik bagi kader-kader partai potensial yang ingin maju dalam pemilihan umum. Jamak dipahami bahwa, pendanaan politik merupakan kendala umum yang ditemui hampir semua kader dalam partai politik di Indonesia. Akibatnya, yang maju dan menang dalam pemilihan umum adalah kader yang memiliki modal politik yang besar meskipun minus prestasi dan kemampuan.

Partisipasi kader perempuan di dalam kegiatan partai juga sangat dipengaruhi oleh dana. Tanpa dana yang cukup dan memadai mustahil bagi perempuan untuk bisa ikut secara total di dalam kegiatan partai. Partai politik memiliki peran dalam mencegah terjadinya kapitalisasi politik yang menyebabkan politisi bermental pragmatis dan membuat partai menjadi alat untuk mencapai kekuasaan semata dengan mengandalkan modal dana yang besar dalam perolehan suara konstituen. Jaminan tanpa mahar politik terbukti mampu menarik kader perempuan untuk berpartisipasi dalam pencalonan anggota legislatif serta menjadi satu bentuk pendidikan politik bagi kader dan masyarakat.

\section{Kesimpulan}

Meski sudah disepakati dalam berbagai konvensi internasional dan berbagai kebijakan pemerintah bahwa perempuan perlu dan penting dilibatkan dalam kehidupan politik, namun fenomena umum diberbagai negara menunjukkan bahwa partisipasi politik kaum perempuan masih rendah. Affirmative action sebagai salah satu bentuk "fast track policies" pada seluruh partai politik merupakan upaya untuk menjamin kaum perempuan terlibat dalam proses politik dan pengambilan keputusan. Adopsi kebijakan affirmative action ini tidak serta merta akan berimplikasi positif terhadap penguatan partisipasi dan keterwakilan politik kaum perempuan.

Oleh karena itu, upaya afirmasi politik partai dalam mendorong keterlibatan perempuan dalam ruang publik dapat dilakukan dengan, 1) Mendorong partai politik sebagai "main gate keepers of democracy" untuk menerapkan secara konsisten kebijakan affirmative action disertai dengan aktivitas pendidikan politik yang intensif dan proses rekrutmen yang mendukung penguatan kapasitas wakil-wakil perempuan; 2) Pemberdayaan perempuan yang berkelanjutan untuk memperkuat klaim mereka mengakses hak memperoleh posisi di institusi politik atau birokrasi; 3) Intensif kampanye publik melalui media atau mobilisasi jejaring gerakan perempuan untuk menggalang dukungan tentang pentingnya keterlibatan kaum perempuan dalam kehidupan politik; dan 4) Pendidikan politik untuk semua kalangan masyarakat yang berfokus pada upaya menghilangkan hambatan ideologis dan kultural bagi kaum perempuan untuk aktif di ranah publik.

\section{Referensi}

A. Rahman H.I. (2007). Sistem Politik Indonesia. Graha Ilmu.

Ardiansa, D. (2016). Menghadirkan Kepentingan Perempuan dalam Representasi Politik di Indonesia. Jurnal Politik, 2(1), 72-98. Retrieved from http://jurnalpolitik.ui.ac.id/index.php/jp/article/view/82/67 
Arikunto, S. (2002). Prosedur Penelitian Suatu Pendekatan Praktek. Jakarta: Rineka Cipta. Arjani, N. L. (2008). Kesetaraan dan Keadilan Gender (KKG) dan Tantangan Global.

INPUT: Jurnal Ekonomi Dan Sosial, 1(2). Retrieved from https://ojs.unud.ac.id/index.php/input/article/view/3181

Ballington, J. (2008). Equality in Politics: A Survey of Women and Men in Parliaments (A. Mash, Ed.). Retrieved from

https://books.google.co.id/books?hl=en\&lr=\&id=ZFd77Twyn3sC\&oi=fn $\mathrm{d} \&$

$\mathrm{pg}=$ PA1\&dq=Ballington, + Julie,$+(2008) .+$ Equality + in + Politics: + A + Survey

to f+Women+and+Men+in+Parliaments, +Inter-

Parliamentary+Union $+:+$ Jenewa + Swiss\&ots $=$ s7-

Kv8ql9A\&sig=BqM8h4Fp-9u9D5OjU1IaOQMmc0U\&

Ballington, J. (2011). Pemberdayaan Perempuan Demi Partai Politik yang Lebih Kuat: Panduan Praktek Terbaik Untuk Meningkatkan Partisipasi Politik Perempuan (M. Popovici, Ed.). Retrieved from https://studylibid.com/doc/421754/pemberdayaan- perempuan-demipartai-politik-yang-lebih-kuat

Budiardjo, M. (2008). Dasar-Dasar Ilmu Politik. Retrieved from https://books.google.co.id/books?hl=en\&lr=\&id=_dZ247rCydIC\&oi=fnd \&p $\quad \mathrm{g}=$ PR11\&dq=udiardjo, + Miriam $++(2008) .+$ DasarDasar+Ilmu+Politik.+Jakarta $+:+$ Gramedia + Pustaka+Utama.\&ots $=z E D R$ 7YZBg\&sig=imfw2r3RXe7jtvdTN7JXENSgP14\&redir_esc $=\mathrm{y} \#_{\mathrm{v}}=$ onep age\&q\&f$=$ false

Cholisin. (2007). Dasar-Dasar Ilmu Politik. Yogyakarta: UNY Press.

Inter-Parliamentary Union. (2010). Women in Parliaments: World and Regional Averages (Statistical Archive). Retrieved from Regional Parliamentary Assemblies website: http://archive.ipu.org/wmn-e/world-arc.htm

Inter-Parliamentary Union. (2011). Women in Parliaments: World and Regional Averages (Statistical Archive). Retrieved December 6, 2019, from Regional Parliamentary Assemblies website: http://archive.ipu.org/wmn-e/worldarc.htm

Khotimah, K. (2009). Diskriminasi Gender Terhadap Perempuan dalam Sektor Pekerjaan. YINYANG: Jurnal Studi Islam, Gender, Dan Anak, 4(1). Retrieved from http://www.ejournal.iainpurwokerto.ac.id/index.php/yinyang/article/view 1226

KPUD Sumenep. (2009). Daftar Perolehan Suara Sah Partai Politik Pemilu Legislatif 2009. Retrieved from Komisi Pemilihan Umum Kabupaten Sumenep website: http://www.kpusumenepkab.go.id

KPUD Sumenep. (2014). Daftar Perolehan Suara Sah Partai Politik Pemilu Legislative 2014. Retrieved from Komisi Pemilihan Umum Kabupaten Sumenep website: http://www.kpusumenepkab.go.id

Mardhatillah, M. (2014). Perempuan Madura Sebagai Simbol Prestise dan Pelaku Tradisi Perjodohan. MUSAWA: Jurnal Studi Gender Dan Islam, 13(2), 168177. Retrieved from http://ejournal.uinsuka.ac.id/pusat/MUSAWA/article/view/895/832 
Moleong, L. J. (2002). Metodologi Penelitian Kualitatif. Bandung: Remaja Rosdakarya. Mukarom, Z. (2008). Perempuan dan Politik: Studi Komunikasi Politik tentang

Keterwakilan Perempuan di Legislatif. MediaTor: Jurnal Komunikasi, 9(2), 257-268. Retrieved from https://ejournal.unisba.ac.id/index.php/mediator/article/view/1125/681 Neumann, S. (1956). Modern Political Parties: Approaches to Comparative Politics. Illinois:

University of Chicago Press.

Patton, M. Q. (1990). Qualitative Evaluation and Research Methods. California: Sage Publications.

Paxton, P., \& Hughes, M. (2007). Women, Politics, and Power: A Global Perspective. Los Angeles: Pine Forge Press.

Prajarto, K. K. Y. dan N. (2005). Hak Asasi Manusia (HAM) di Indonesia: Menuju Democratic Goaernance. Jurnal Ilmu Sosial Dan Ilmu Politik, 8(3), 291308.

Suharno. (2004). Diktat Kuliah Sosiologi. Retrieved from http://staffnew.uny.ac.id/upload/132255131/pendidikan/Karya+A+-

+ Diktat+Kuliah+Sosiologi+Politik.pdf

Sulistyo, A. I. (2006). Prinsip Dasar, Perumusan Masalah, dan Pengumpulan Data Penelitian Naturalistik. Yogyakarta.

Surbakti, R. (1992). Memahami Ilmu Politik. Jakarta: Gramedia Widya Sarana.

Suseno, N. (2013). Representasi Politik: Perkembangan dari Adjektiva ke Teori. Depok: Puskapol UI.

Susiana, S., \& Cahyaningrum, D. (2010). Implementasi pasal tentang affirmative action dalam Undang-Undang Nomor 10 tahun 2008 tentang Pemilu Anggota DPR, DPD, dan DPRD (studi di Provinsi Maluku Utara). Kajian, 15(1), 467-478. https://doi.org/10.22212/KAJIAN.V15I1.382

Warits, A. (2012). Artikulasi Politik Perempuan Madura (Studi atas Hambatan Kultural dan Tafsir Agama pada Partisipasi Politik Perempuan di Sumenep). KARSA: Journal of Social and Islamic Culture, 19(2), 183-199. https://doi.org/10.19105/karsa.v19i2.65

Wibowo, D. E. (2011). Peran Ganda Perempuan dan Kesetaraan Gender. Muwazah: Jurnal Kajian Gender, 3(1), 357-363. Retrieved from http://ejournal.iainpekalongan.ac.id/index.php/Muwazah/article/view/6/6

Yuriadi. (2016). Konstruksi Perempuan dalam Wajah Madura. In T. H. Rahmad, S. Hadiwibowo, M. H. Widjanarko, \& L. O. Wahyudi (Eds.), Prosiding Seminar Nasional Gender dan Budaya Madura III "Madura dalam Perspektif Budaya, Gender, Politik, Industrialisasi, Kesehatan dan

Pendidikan." Retrieved from http://lppm.trunojoyo.ac.id/budayamadura/wpcontent/uploads/2016/10/2-1.-ARTIKEL.pdf 


\section{Hasil Wawancara}

Anonim, pengurus harian PPP, PKB, dan Demokrat. (2019). Sumenep, Senin 6 Mei 2019.

Anonim, kader PPP, PLN, dan Demokrat. (2019). Sumenep, 13 Mei 2019.

Anonim, kader PPP, PLN, dan Demokrat. (2019). Sumenep, 20 Mei 2019. Ningsih, kader PPP, Sumenep. (2019). Sumenep, Senin 27 Mei 2019.

Anonim, kader PPP, PKB, Gerindra, PAN, dan Demokrat. (2019). Sumenep, 3 Juni 2019. 